\title{
EPIPHYSEAL CLOSURE TIME OF RADIUS AND ULNA BONES OF THE PROXIMAL SECTION
}

\author{
Tiara Mayang Pratiwi Lio ${ }^{1}$, Toetik Koesbardiati ${ }^{1}$, Achmad Yudianto ${ }^{1}$, Rosy Setiawati ${ }^{2}$ \\ ${ }^{1}$ Master Program of Forensic Science, Faculty of Medicine, Universitas Airlangga, ${ }^{2}$ Department of Radiology, \\ Dr. Soetomo Hospital, Surabaya, Indonesia
}

\begin{abstract}
ABSTRAK
Identifikasi usia forensik bertujuan untuk menentukan cara yang paling akurat usia kronologis seseorang yang tidak diketahui atau diragukan keasliannya yang terlibat dalam proses hukum. Salah satu metode yang digunakan adalah dengan menilai penutupan epifisis pada tulang melalui pemeriksaan radiologi. Masalah utama penggunaan metode ini berhubungan dengan relevansi dan representatif populasi referensi yang tersedia. Setiap populasi dapat memiliki waktu penutupan yang berbeda-beda karena dipengaruhi oleh genetik dan gizi, sehingga sangat diperlukan data yang dapat mewakili setiap populasi tersebut. Pemeriksaan radiologi tulang siku dari 30 pasien laki-laki usia 11-30 tahun dan 18 pasien perempuan usia 14-28 tahun di RSUD Dr. Soetomo, Surabaya selama periode Januari-April 2016, dilakukan untuk menentukan waktu penutupan epifisis dari tulang radius dan ulna bagian proximal. Penelitian ini menggunakan rancangan penelitian deskriptif cross-sectional. Sebagai simpulan, epifisis tulang radius dan ulna bagian proximal menutup sempurna di usia 16 tahun pada laki-laki dan 14 tahun pada perempuan. (FMI 2018;54:123-128)
\end{abstract}

Kata kunci: Usia; penutupan epifisis; proximal; radius; ulna

\begin{abstract}
Accurate determination of age is important in the legal process; when a person's age is unknown or must be authenticated, a forensic age identification method must be applied. One of such methods is to assess the epiphyseal closure on the bone through radiological examination. The main problem associated with the use of this method is the relevance of the reference population provided because epiphyseal closure is influenced by genetics and nutrition. This method needs data to represent each population. Radiological examination of elbow bones of 30 male patients aged 11-30 years and 18 female patients aged 14-28 years in Dr. Soetomo Hospital, Surabaya from January to April 2016 was carried out to determine the time of epiphyseal closure of the radius and ulna distal section. This was cross-sectional descriptive study. In conclusion, epiphyseal closure of proximal radius and ulna is complete at age 16 in males and 14 in females. (FMI 2018;54:123-128)
\end{abstract}

Keywords: Age; epiphyseal closure; proximal; radius; ulna

Correspondence: Tiara Mayang Pratiwi Lio, Master Program of Forensic Science, Faculty of Medicine, Universitas Airlangga, Surabaya, Indonesia. Phone: 082292534410. Email: tiaramayangpratiwilio@yahoo.com

\section{INTRODUCTION}

Identification or recognition of one's identity was originally developed for the sake of occuracy in the process of investigation of a criminal offense, especially in criminal problem solving. With the development of science and social problems, this method of identification can be used in a variety of civil cases, involving dead or live victims as in accidents on land, sea, or air, in cases of terrorism, war, natural disasters, murder, illegal migration, questionable identities and the like (Martin \& Anderson 2014, Anstett \& Dreyfus 2015, Bassed 2012, Mallett et al 2014).

Age identification can be undertaken on a person alive or dead. Estimated age forms part of the identification process of victims in the case of murder, abortion of the fetus, or a mass disaster. In the case of mass disasters, age estimation can simplify identification of victims by grouping victims of similar age. In addition to the criminal or civil law cases, age identification is also required to estimate the age of an individual to distinguish between individuals, age falsification of employment, marriage, athlete, child custody, immigration, or rape. Legal proof of age will be important to determine whether the individual belongs in the category of a child or an adult, due to the differences in the legal or judicial process in children and adult. Age identification is also proving valuable when a birth certificate is missing or doubtful authenticity (Vieira 2011, Eikvil et al 2012, Burns 2013, Koesbardiati 2012).

Chronological age is the age calculation from birth until the time of the calculation of one's age. Biological age is the age calculation based on one's own biological 
maturity. Chronological age can be predicted as the increasing stage of growth and the development of the body structure in the form of physical changes, known as biological age. The biological age is constant so that each stage of the process of change can be attributed to the age of an individual (Iscan \& Steyn 2013, TersigniTarrant \& Shirley 2013).

The human body grows and becomes mature with age, especially in children and adolescents. Therefore, the main idea behind the medical method is to compare the measurement of physical maturity of the body with age. However, since the determination of both the framework and the development of teeth is varied, the result of each method has been uncertain when applied to an individual. There are also issues relating to the relevance and representative of the reference population where biological age is influenced by genetic and nutrition factors so that there will always be a biological variation and uncertainty associated with age estimation (Berg \& Ta'ala 2015, Ritz-Time et al 2000, TersigniTarrant \& Shirley 2013).

The most frequent problem encountered in the identification of age is associated with the relevance and representativeness of the reference population. Biological age is influenced by genetics and nutrition so that there will always be a biological variation and uncertainty associated with the age estimation. In Indonesia, this is performed using textbooks that come from the western countries as a guide in determining age because there is no anthropometry guide specifically for Indonesian people.

Today, in some countries there is no certainty about which method used for age identification. The majority of countries assess age based on medical examination of bone and/or teeth development, physical appearance and interview, while some countries rely on non-medical assessment only. Many countries also use a variety of precision margins for each of the different methods and approaches for incorporating the results when some of the methods applied (Eikvil et al 2012).

Age identification through the body framework can be determined based on the amount of bone that has emerged, the union of the epiphysis with the diaphysis (epiphyseal closure) in the long bones, morphological changes in the symphysis pubis, closure degree of sutures or degrees of calcification and teeth eruption is undertaken either by using macroscopic, microscopic or radiographic examination (Indriati 2010).

Age identification based on the epiphysis closure can be done based on the assessment of epiphysis of bones located in the hand area, because based on previous research, it is considered the most accurate and easiest area to be undertaken. The closure of the epiphysis in the hand area is estimated to begin from the age of 11 years and closed completely at the age of 28-30 years (Black et al 2010).

The age identification based on the body framework is generally done using bone that has been cleared of the soft tissue. It is obviously going to take time in the process of identification if the amount of soft tissue present in the victim is still in abundance. In living humans, radiological evaluation will greatly assist the identification process of anthropological parameters because we can see the inside of living human body with soft tissue present (Stimson \& Mertz 1997, Thali et al 2011, Mallett et al 2014). The radiographic tools used are a conventional X-ray or radiography, Computed Tomography scan (CT scan), Magnetic Resonance Imaging (MRI) and Untrasonography or ultrasound. Each tool has its advantages and disadvantages (Schmidt et al 2011, Kellinghaus et al 2010, Serin et al 2016). The most common problems arise in the use of more modern radiographic media are radiation effects, images produced by the media, and the availability of the tools. Therefore, the use of conventional radiology or X-ray is the most recommended one.

Based on the need for forensic age identification in Indonesia, the existing radiological tool generally available in all regions is the X-ray. In the other hand, there is an issue relating to the relevance and representativeness of the reference population where biological age is influenced by genetic and nutritional factors. Therefore, it is necessary to study epiphyseal closure time by an X-ray profile of proximal radius and ulna of male and female. Hopefully, this study can be applied as a reference for research and a tool for forensic age identification in the future.

\section{MATERIALS AND METHODS}

The study used secondary data from the medical record on results of X-rays of the patient's elbow at Dr. Soetomo Hospital, Surabaya from January to April, 2016. The inclusion criteria were 11-30 years old male and female, did not have disorders in growth and development of bones, and the images met a good standard of X-rays. The samples were taken with the permission of the head of radiological installations and passed the ethical clearance of Dr. Soetomo Hospital, Surabaya. The samples were assessed to determine the level of epiphyseal closure on proximal radius and ulna in a certain age. Chronological age is the age calculated beginning from the moment of one's birth until the time of the calculation of the age. The measurement is by 
looking at the data or information on a patient's medical record. The data are obtained in the form of the patient's age in years. The epiphyseal closure time is when epiphysis merges with the diaphysis. The measurement is by looking at the profile of epiphyseal closure on radiographs. The data are obtained in the form of statements on the degrees or levels of epiphyseal closure.

\section{Level of epiphyseal closure}

Epiphyseal closure is one of the most commonly used methods in determining someone's chronological age. Epiphyseal closure is a level of maturity of bone growth that describes one's biological age. There are several classifications in determining the level of epiphyseal closure, one requires detection of one of four categories, namely 0, 1, 2, and 3. Epiphyseal closure is classified as follows: 0: If there is no closure at all; 1: If there has been epiphyseal closure which is less than half of the area of the epiphyseal; 2: If there has been a half portion of the epiphyseal closure of the epiphyseal area; $3:$ If the epiphyseal closure is totally completed.
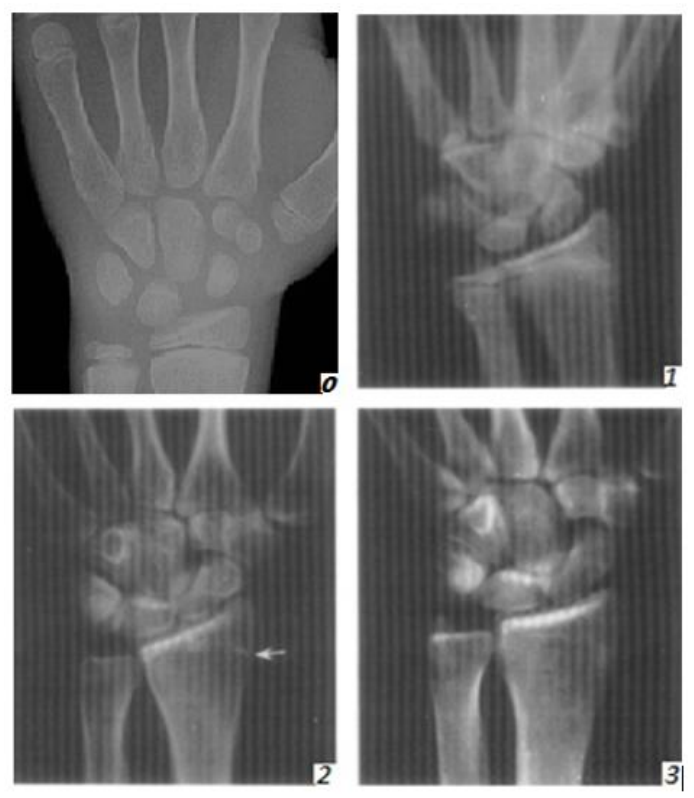

Fig. 1. Level of epiphyseal closure. $0=$ no closure. $1=$ closure less than half of the epiphyseal area. $2=$ closure more than half of the epiphyseal area. $3=$ it has covered the entire epiphyseal area (Gilsanz \& Ratib 2012, Sahni \& Jit 1995).

\section{RESULTS}

The results of epiphyseal closure time on proximal radius and ulna of male patients at Dr. Soetomo
Hospital, Surabaya is shown in Table 1 and the research results of the epiphyseal closure time on proximal radius and ulna of female patients at Dr. Soetomo Hospital, Surabaya is shown in Table 2.

Radiological examination of elbow bones of 30 male patients showed that the epiphyseal closure of proximal radius and ulna occurred from at the age of 11 years. In the age of 11-14 years, the closure occurred in more than half of the epiphysis and it began to close completely at the age of 16 years.

Fig. 2 shows that epiphyseal closure of proximal radius in males occurs from at the age of 11 years. In the age of 11-14 years, the closure occurred in more than half of the epiphysis, indicated by blue charts, and it began to close completely in the age of 16 years, indicated by green charts.

Fig. 3 shows that epiphyseal closure of proximal ulna in males occurs from the age of 11 years. In the age of 1114 years, the closure occurred in more than half of the epiphysis, indicated by blue charts, and it began to close completely in the age of 16 years, indicated by green charts. Based on Table 2, radiological examination of elbow bones of 18 female patients shows that the epiphyseal closure of proximal radius and ulna occurs from age of 14 years and has been completely closed at that age.

Fig. 4 shows that epiphyseal closure of proximal radius in females occurs from age of 14 years and has been completely closed at that age indicated by yellow charts. Fig. 5 shows that epiphyseal closure of proximal ulna in females occurs from age of 14 years and has been completely closed at that age indicated by yellow charts.

\section{DISCUSSION}

\section{Epiphyseal closure of proximal radius in males}

The research results showed that epiphyseal closure of the proximal radius in males at the age of 11-14 years have covered the area of more than half of the epiphysis and it began to close completely at the age of 16 years. This shows a difference from previous studies conducted in Europe wherein the epiphyseal closure of proximal radius in males had completed at the age of 14-17 years, while at the age of 14 in this study we found that the epiphysis in all samples have not been completely closed. This can be caused by genetic factors as well as hormonal and nutritional differences between Asian people, particularly Indonesia, and European-American population (Black et al 2010). 
Table 1. The epiphyseal closure time on proximal radius and ulna in males

\begin{tabular}{|c|c|c|c|c|c|c|c|c|c|c|}
\hline \multirow[t]{2}{*}{ No } & \multirow{2}{*}{$\begin{array}{l}\text { Chronological } \\
\text { age (year) }\end{array}$} & \multirow[t]{2}{*}{ Sample } & \multicolumn{4}{|c|}{$\begin{array}{l}\text { Degree of epiphyseal closure of } \\
\text { proximal radius }\end{array}$} & \multicolumn{4}{|c|}{$\begin{array}{c}\text { Degree of epiphyseal closure of } \\
\text { proximal ulna }\end{array}$} \\
\hline & & & 0 & 1 & 2 & 3 & 0 & 1 & 2 & 3 \\
\hline 1 & 11 & 1 & & & 1 & & & & 1 & \\
\hline 2 & 12 & 1 & & & 1 & & & & 1 & \\
\hline 3 & 13 & & & & & & & & & \\
\hline 4 & 14 & 3 & & & 3 & & & & 3 & \\
\hline 5 & 15 & & & & & & & & & \\
\hline 6 & 16 & 2 & & & & 2 & & & & 2 \\
\hline 7 & 17 & 3 & & & & 3 & & & & 3 \\
\hline 8 & 18 & & & & & & & & & \\
\hline 9 & 19 & 1 & & & & 1 & & & & 1 \\
\hline 10 & 20 & 1 & & & & 1 & & & & 1 \\
\hline 11 & 21 & & & & & & & & & \\
\hline 12 & 22 & 2 & & & & 2 & & & & 2 \\
\hline 13 & 23 & 3 & & & & 3 & & & & 3 \\
\hline 14 & 24 & 1 & & & & 1 & & & & 1 \\
\hline 15 & 25 & 1 & & & & 1 & & & & 1 \\
\hline 16 & 26 & 2 & & & & 2 & & & & 2 \\
\hline 17 & 27 & 4 & & & & 4 & & & & 4 \\
\hline 18 & 28 & 2 & & & & 2 & & & & 2 \\
\hline 19 & 29 & 2 & & & & 2 & & & & 2 \\
\hline \multirow[t]{2}{*}{20} & 30 & 1 & & & & 1 & & & & 1 \\
\hline & Total & 30 & & & 5 & 25 & & & 5 & 25 \\
\hline
\end{tabular}

Notes: Epiphyseal closure. $0=$ no closure. $1=$ closure less than half of the epiphyseal area. $2=$ closure more than half of the epiphyseal area. $3=$ it has covered the entire epiphyseal area

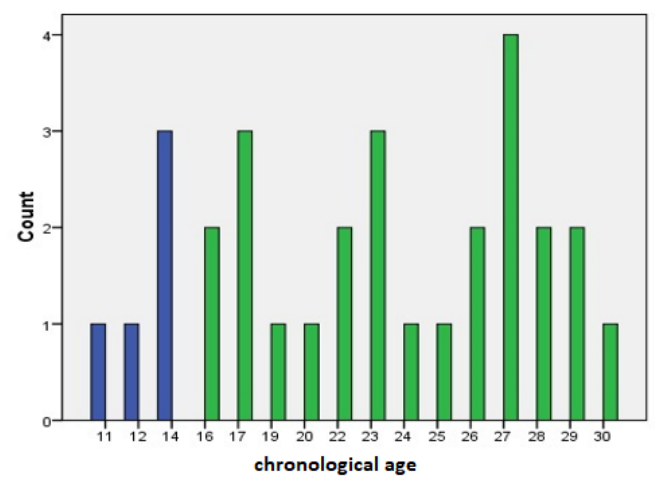

2= closed more than half of epiphyseal area

Fig. 2. Epiphyseal closure time of the radius proximal in males.

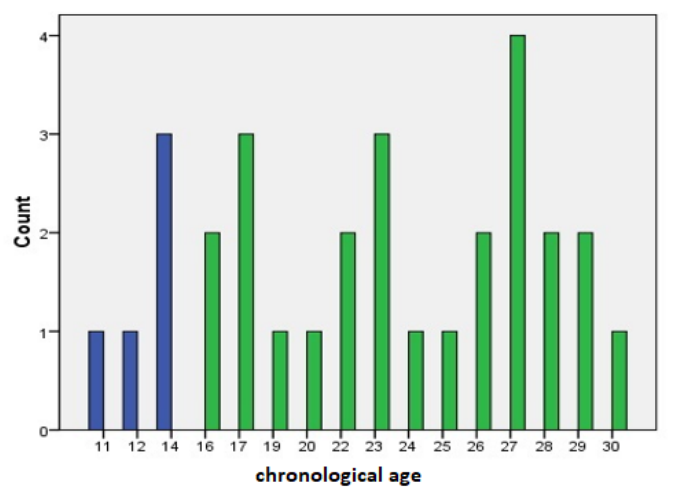

$2=$ closed more than half of epiphyseal area
$3=$ completely closed

Figure 3. Epiphyseal closure time of the proximal ulna in males. 
Table 2. The epiphyseal closure time on proximal radius and ulna in females

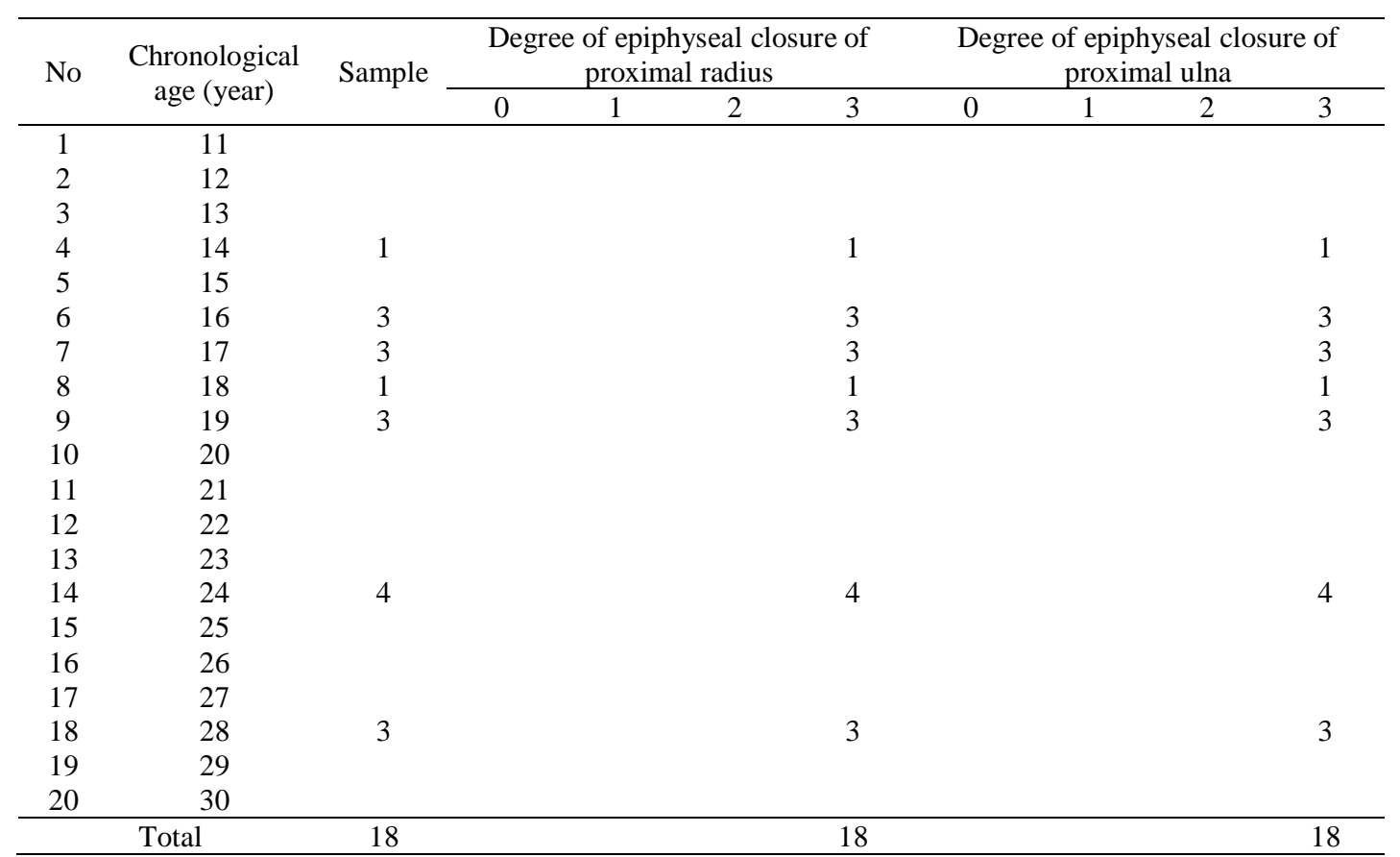

Notes: Epiphyseal closure. $0=$ no closure. $1=$ closure less than half of the epiphyseal area. $2=$ closure more than half of the epiphyseal area. $3=$ it has covered the entire epiphyseal area

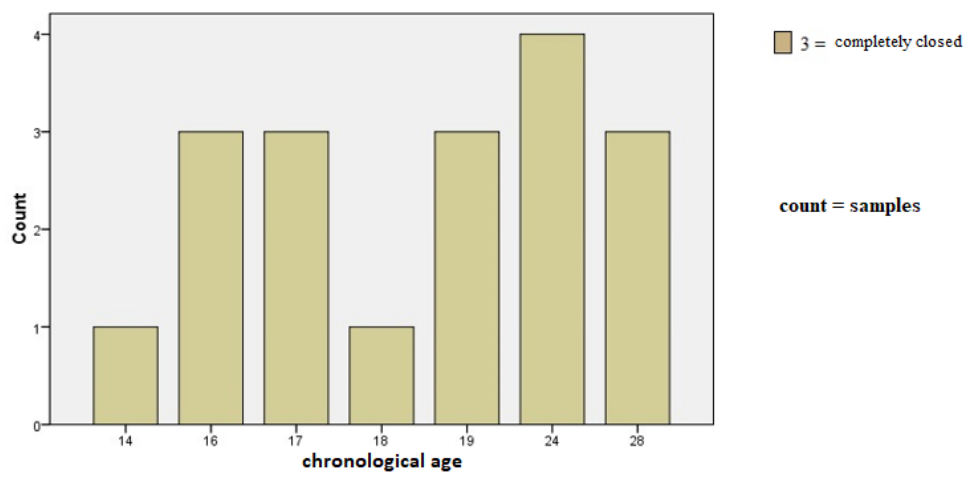

Fig. 4. Epiphyseal closure time of the proximal radius in females.

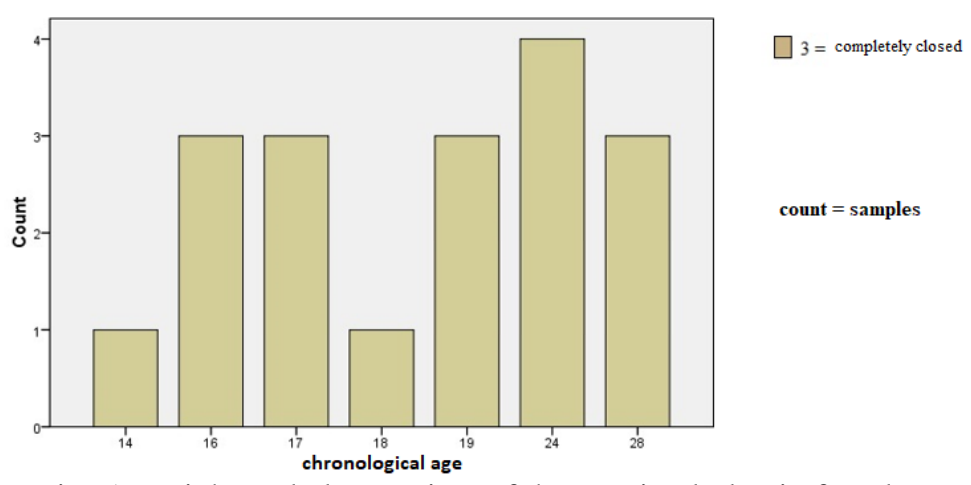

Fig. 5. Epiphyseal closure time of the proximal ulna in females. 


\section{Epiphyseal closure of proximal ulna in males}

The result of this study showed that the epiphyseal closure of proximal ulna in males at the age of 11-14 years had covered more than half of the epiphysis and it began to close completely at the age of 16 years. This shows the difference with previous studies conducted in Europe in which the epiphyseal closure of proximal ulna in males has closed completely at the age of 13-16 years. This can be caused by genetic factors as well as hormonal and nutritional differences between Asian people, particularly Indonesia, and European-American population (Black et al 2010).

\section{Epiphyseal closure of proximal radius in females}

This current study shows that epiphyseal closure of proximal radius in females with a vulnerable age of 1428 years, occurs from the age of 14 years and has closed completely at that age. The previous study conducted in Europe and America showed that the epiphyseal closure of proximal radius in females occurred since the age of 11-13 years. The weakness of the study was the absence of an X-ray photograph of females aged 11-13 years, so the profile of proximal radius closure in females at the age could not be identified (Black et al 2010).

\section{Epiphyseal closure of proximal ulna in females}

Based on this study, the epiphyseal closure of proximal ulna in females aged 14-28 years, occurs from age of 14 years and has completely closed at that age. The previous study conducted in Europe and America showed that epiphyseal closure of ulna proximal of female occurred from the age of 12-14 years. The weakness of the study was the absence of radiographic ulna and ulna proximal of female aged 12-13 years, so the profile of proximal ulna closure in females at that age could not be identified (Black et al 2010).

\section{CONCLUSION}

Epiphyseal closure of proximal radius and ulna is complete at age 16 in males and 14 in females.

\section{REFERENCES}

Anstett E, Dreyfus (2015). Human remains and identification: Mass violence, genocide, and the "forensic turn". J.-M. eds. Manchester, Manchester University Press

Bassed RB (2012). Advances in forensic age estimation. Forensic Science Medicine and Pathology 8, 194-196
Berg GE, Ta'ala SC (2015). Biological affinity in forensic identification of human skeletal remains: beyond black and white, Boca Raton: CRC Press.

Black S, Payne-James J, Aggrawal A (2010). Age estimation in the living. United Kingdom, A John Wiley \& Sons

Burns KR (2013). Forensic anthropology training manual. 3rd ed. USA, Pearson Education

Eikvil L, et al (2012). Age estimation in youths and young adults. A summary of the needs for methodological research and development. Norwegian, Norsk Regnesentral

Gilsanz V, Ratib O (2012). Hand bone age: A digital atlas of skeletal maturity. 2nd ed. Berlin, SpringerVerlag

Indriati E (2010). Antropologi Forensik. Yogyakarta, Gadjah Mada University Press

Iscan MY, Steyn M (2013). The human skeleton in forensic medicine. 3rd ed. USA, Charles C Thomas

Kellinghaus M, et al (2010). Forensic age estimation in living subjects based on the ossification status of the medial clavicular epiphysis as revealed by thin-slice multidetector computed tomography. International Journal of Legal Medicine 124, 149-154

Koesbardiati T (2012). Bahan ajar antropologi forensik. Surabaya, PT. Revka Petra Media

Mallett X, Blythe T, Berry R (2014). Advances in forensic human identification. Boca Raton, CRC Press

Martin DL, Anderson CP (2014). Bioarchaeological and forensic perspectives on violence: How violent death is interpreted from skeletal remain. United Kingdom, Cambridge University Press

Ritz-Time S, et al (2000). Age estimation: The state of the art in relation to the specific demands of forensic practise. International Journal Legal Medicine 113, 129-136

Sahni D, Jit I (1995). Forensic Science Time of fusion of epiphyses at the elbow and wrist joints in girls of Northwest India. Forensic Science International 74, 47-55

Schmidt S, et al (2011). Sonographic evaluation of apophyseal ossification of the iliac crest in forensic age diagnostics in living individuals. International Journal Legal Medicine 125, 271-276

Serin J, et al (2016). Contribution of magnetic resonance imaging of the wrist and hand to forensic age assessment.

Stimson PG, Mertz CA (1997). Forensic Dentistry. Boca Raton, CRC Press

Tersigni-Tarrant MA, Shirley NR. eds (2013). Forensic Anthropology: An introduction. Boca Raton, CRC Press

Thali MJ, Viner MD, Brogdon BG (2011). Brogdon's forensic radiology. 2nd ed. Boca Raton, CRC Press

Vieira DN (2011). Forensic medicine - From old problems to new challenges. Croatia, InTech 